\title{
Price-Setting Mixed Duopoly, Privatization and Subsidization
}

\author{
Kazuhiro Ohnishi
}

Institute for Basic Economic Science, Japan

\begin{abstract}
This paper focuses on the role that production subsidies play in a Bertrand mixed duopoly. The paper examines four regimes: mixed and private duopoly, each with and without subsidies. The results of this study are compared with the findings of the existing Cournot mixed market literature. As a result, the paper shows that that the introduction of production subsidies into the analyses of Bertrand and Cournot mixed markets can improve social welfare.
\end{abstract}

Keywords Mixed Duopoly Model, Price Competition, Privatization, Subsidization

\section{Introduction}

Mixed oligopolies are common in developed and developing countries as well as in former communist countries. Public firms compete with private firms in many industries, such as the airline, banking, broadcasting, education, electricity, health care, home loans, life insurance, overnight delivery, rail, shipbuilding, telecommunications, and tobacco. The pioneering theoretical work on mixed oligopoly was done by[1]. Since then, the analysis of mixed market models that incorporate public firms has received increasing attention and has been widely performed by many researchers (see, for example,[2-16]). ${ }^{1}$

As is well known, there has been a worldwide wave of privatization of public enterprises since the nineteen-eighties. Therefore, the theoretical studies of privatization are often studied in the context of mixed market models where state-owned welfare-maximizing public firms interact with profit-maximizing private firms (see, for example,[22-41]). However, most studies analyze privatization in mixed markets where public and private firms compete in quantities.

Therefore, we study privatization in price-setting mixed duopoly competition. We extend the analysis of[25], which studies the role that production subsidies play in a Cournot quantity-setting mixed market and how they may influence the privatization decision.[25] presents three main results. First, if subsidies are used before and after privatization, then privatization does not change welfare. Second, if subsidies are used only before privatization, then privatization always

\footnotetext{
* Corresponding author:

ohnishi@e.people.or.jp (Kazuhiro Ohnishi)

Published online at http://journal.sapub.org/m2economics

Copyright $(02012$ Scientific \& Academic Publishing. All Rights Reserved
}

\footnotetext{
${ }^{1}$ See, for example,[17-21] for excellent surveys.
}

lowers welfare. Third, the subsidy contributes to overall efficiency in a mixed market due to cost distribution effects. In addition,[26, 27] consider Stackelberg competition in which the public firm becomes the leader,[28] considers partial privatization introduced by[31], and[29] examines a mixed oligopoly that each private firm's objective is not profit maximization. As a result,[25-29] show that the optimal subsidy, equilibrium output level, all firms' profits and social welfare are identical before and after privatization of a public firm in a quantity-setting mixed market.

We investigate the role that production subsidies play in a price-setting mixed market. We consider the following four regimes: mixed and private duopoly, each with and without subsidies. We solve and compare the four models. In addition, our results are compared with the findings of quantity-setting mixed market model by[25].

The remainder of this paper is organized as follows. In Section 2, we describe the basic setting. Section 3 solves the four models. Section 4 compares the four regimes. Finally, Section 5 concludes the paper.

\section{The Basic Setting}

There is an industry composed of one state-owned welfare-maximizing public firm and one profit-maximizing private firm producing imperfectly substitutable goods. In the remainder of this paper, subscripts 0 and 1 denote the public firm and the private firm, respectively. In addition, when $i$ and $j$ are used to refer to firms in an expression, they should be understood to refer to 0 and 1 with $i \neq j$. There is no possibility of entry or exit. On the consumption side, there is a continuum of consumers of the same type whose utility function is linear. Following $[42,43]$, we assume that the representative consumer maximizes $U\left(q_{0}, q_{1}\right)-p_{0} q_{0}-p_{1} q_{1}$, where $q_{i}$ is the amount of good $i$ and $p_{i}$ is its price. The function $U\left(q_{0}, q_{1}\right)$ is quadratic, 
strictly concave and symmetric in $q_{0}$ and $q_{1}$ : $U\left(q_{0}, q_{1}\right)=a\left(q_{0}+q_{1}\right)-\left(q_{0}^{2}+2 b q_{0} q_{1}+q_{1}^{2}\right) / 2$, where $a>0$ and $0<b<1$. The demand function is given by

$$
q_{i}=\frac{a(1-b)-p_{i}+b p_{j}}{1-b^{2}}
$$

where $b$ is a measure of the degree of substitutability among products. For the sake of simplicity, we assume $b=0.5$. Each firm's profit is given by

$$
\pi_{i}=\left(p_{i}-c+s\right) q_{i}
$$

where $c$ is the total cost for each unit of output and $S$ is the subsidy for each unit of output. We assume $0<c<a$ to assure that the production levels of firms are positive.

Social welfare, defined as the sum of consumer surplus plus profits less the cost of subsidy, is given by

$$
W=C S+\pi_{0}+\pi_{1}-s\left(q_{0}+q_{1}\right)
$$

where $C S=2\left[p_{0}^{2}-p_{0} p_{1}+p_{1}^{2}+a\left(a-p_{0}-p_{1}\right)\right] / 3$

We consider four regimes: mixed and private duopoly, each with and without subsidies. In the regimes without subsidies, a simple Bertrand price-setting game is constructed and solved. In the regimes with subsidies, a two-stage game is constructed, wherein the government sets the subsidy in the first stage, and in the second stage each firm observes the subsidy and simultaneously chooses its price.

\section{Results}

In the mixed duopoly models (Subsections 3.1 and 3.2), the public firm chooses $p_{0}$ to maximize social welfare (3), and in the private duopoly models (Subsections 3.3 and 3.4), it is privatized and therefore maximizes its own profit (2).

\subsection{Unsubsidized Mixed Duopoly}

When there is no subsidy ( $s=0)$, the Bertrand equilibrium values of prices, outputs, profits, consumer surplus and welfare are presented as follows:

$$
\begin{gathered}
p_{1}^{\mathrm{M}}(0)=\frac{2 a+5 c}{7}, p_{0}^{\mathrm{M}}(0)=\frac{a+6 c}{7} \\
q_{1}^{\mathrm{M}}(0)=\frac{8(a-c)}{21}, q_{0}^{\mathrm{M}}(0)=\frac{2(a-c)}{3} \\
\pi_{1}^{\mathrm{M}}(0)=\frac{16(a-c)^{2}}{147}, \pi_{0}^{\mathrm{M}}(0)=\frac{2(a-c)^{2}}{21} \\
C S^{\mathrm{M}}(0)=\frac{62(a-c)^{2}}{147} \\
W^{\mathrm{M}}(0)=\frac{92(a-c)^{2}}{147}
\end{gathered}
$$

Note that the price of the public firm is lower than that of the private firm. Also note that the public firm earns a strictly positive profit.

\subsection{Subsidized Mixed Duopoly}

There are two stages: in the first stage the government sets the output subsidy to maximize social welfare; in the second stage each firm simultaneously and independently chooses its price conditional on the subsidy. The game is solved by backward induction to obtain a subgame perfect Nash equilibrium. Maximizing (2) and (3) simultaneously, we obtain the second-stage equilibrium prices in terms of the subsidy $s$ :

$$
p_{1}^{\mathrm{M}}(s)=\frac{2 a+5 c-4 s}{7}, p_{0}^{\mathrm{M}}(s)=\frac{a+6 c-2 s}{7}
$$

We now solve the first stage of the game. In the first stage, the government, taking into account how firms will react to the subsidy, maximize (3); the solution to this problem yields the optimal subsidy:

$$
s^{*}=\frac{a-c}{2}
$$

Note that $s^{*}$ is strictly positive. Therefore, the government will always grant a positive subsidy.

From (9) and (10), we derive the following subgame perfect Nash equilibrium outcomes:

$$
\begin{gathered}
p_{1}^{\mathrm{M}}\left(s^{*}\right)=p_{0}^{\mathrm{M}}\left(s^{*}\right)=c \\
q_{1}^{\mathrm{M}}\left(s^{*}\right)=q_{0}^{\mathrm{M}}\left(s^{*}\right)=\frac{2(a-c)}{3} \\
\pi_{1}^{\mathrm{M}}\left(s^{*}\right)=\pi_{0}^{\mathrm{M}}\left(s^{*}\right)=\frac{(a-c)^{2}}{3} \\
C S^{\mathrm{M}}\left(s^{*}\right)=\frac{2(a-c)^{2}}{3} \\
W^{\mathrm{M}}\left(s^{*}\right)=\frac{2(a-c)^{2}}{3}
\end{gathered}
$$

Note that each firm sets a price that equals $c$. We can now state the following proposition.

Proposition 1. When optimal subsidies are used in a price-setting mixed market, price is equalized between public and private firms, increasing total output, and increasing social welfare.

\subsection{Unsubsidized Private Duopoly}

In this subsection, we solve for the Bertrand equilibrium outcomes of the unsubsidized private duopoly game, wherein each firm maximizes its own profit. The results can be obtained as follows:

$$
\begin{array}{r}
p_{i}^{\mathrm{P}}(0)=\frac{a+2 c}{3} \\
q_{i}^{\mathrm{P}}(0)=\frac{4(a-c)}{9} \\
\pi_{i}^{\mathrm{P}}(0)=\frac{4(a-c)^{2}}{27} \\
C S^{\mathrm{P}}(0)=\frac{8(a-c)^{2}}{27} \\
W^{\mathrm{P}}(0)=\frac{16(a-c)^{2}}{27}
\end{array}
$$




\subsection{Subsidized Private Duopoly}

There are two stages: in the first stage the government sets the output subsidy to maximize social welfare; in the second stage each profit-maximizing firm simultaneously and independently chooses its price conditional on the subsidy. The game is solved by backward induction to obtain a subgame perfect Nash equilibrium. Maximizing (2) simultaneously, we obtain the second-stage equilibrium in terms of the subsidy $s$ :

$$
p_{i}^{\mathrm{P}}(s)=\frac{a+2 c-2 s}{3}
$$

In the first stage, the government, taking into account how firms will react to the subsidy, maximize (3). It happens that the optimal subsidy, prices, outputs, profits, consumer surplus and welfare in this case are identical with those in Subsection 3.2, subsidized mixed duopoly. Therefore, expressions (11) - (15) also represent the relevant expressions for the subsidized private duopoly. We can now state the following proposition.

Proposition 2. Optimal production subsidies can increase total output and welfare in a price-setting private market.

\section{Comparisons}

First, we compare the two unsubsidized regimes (Subsections 3.1 and 3.3). The difference between welfare in the unsubsidized mixed and private duopoly regimes is

$$
W^{\mathrm{M}}(0)-W^{\mathrm{P}}(0)=\frac{44(a-c)^{2}}{1323}
$$

The result of this comparison is stated as follows. In the absence of subsidies, welfare is higher before privatization than after privatization.

Second, we compare the subsidized mixed duopoly (Subsection 3.2) with the unsubscribed private duopoly (Subsection 3.3). From (15) and (20), we see that welfare is higher in the subsidized mixed market than in the unsubsidized private market. Proposition 3 presents this result.

Proposition 3. If optimal subsidies are used before but not after privatization of a public firm in a price-setting mixed market, then welfare is lower after privatization.

Finally, we compare the two subsidized regimes (Subsections 3.2 and 3.4). The optimal subsidy, prices, outputs, profits, consumer surplus and welfare in the subsidized mixed market are identical with those in the subsidized private market. This comparative result is stated by the following proposition.

Proposition 4. If optimal subsidies are used before and after privatization of a public firm in a price-setting mixed market, then the optimal subsidy and welfare are unchanged.

\section{Conclusions}

We have investigated the role that production subsidies play in a Bertrand mixed market and have considered the following four regimes: mixed and private duopoly, each with and without subsidies. We have found that our results are the same as those of Cournot mixed market models. As a result of these studies, we find that the introduction of production subsidies into the analyses of Bertrand and Cournot mixed markets can improve social welfare.

\section{REFERENCES}

[1] Merrill, W., Schneider, N., 1966. Government firms in oligopoly industries. Quarterly Journal of Economics 80 (3), 400-412.

[2] Ware, R., 1986. A model of public enterprise with entry. Canadian Journal of economics 19 (4), 642-655.

[3] Sertel, M. R., 1988. Regulation by participation. Journal of Economics 48 (2), 111-134.

[4] Cremer, H., Marchand, M., Thisse, J.-F., 1991. Mixed oligopoly with differentiated products. International Journal of Industrial Organization 9 (1), 43-53.

[5] Delbono, F., Rossini, G., 1992. Competition policy vs horizontal merger with public, entrepreneurial, and labor-managed firms. Journal of Comparative Economics 16 (2), 226-240.

[6] Delbono, F., Denicolò, V., 1993. Regulating innovative activity: the role of public firm. International Journal of Industrial Organization 11 (1), 35-48.

[7] Nett, L., 1994. Why private firms are more innovative than public firms. European Journal of Political Economy 10 (4), 639-653.

[8] Willner, J., 1994. Welfare maximization with endogenous average costs. International Journal of Industrial Organization $12(3), 373-386$.

[9] Delbono, F., Scarpa, C., 1995. Upward-sloping reaction functions under quantity competition in mixed oligopolies. Bulletin of Economic Research 47 (4), 341-346.

[10] Pal, D., 1998. Endogenous timing in a mixed oligopoly. Economics Letters 61 (2), 181-185.

[11] Poyago-Theotoky, J., 1998. R\&D competition in a mixed duopoly under uncertainty and easy imitation. Journal of Comparative Economics 26 (3), 415-428.

[12] Fjell, K., Heywood, J. S., 2002. Public Stackelberg leadership in a mixed oligopoly with foreign Firms. Australian Economic Papers 41 (3), 267-281.

[13] Bárcena-Ruiz, J. C., Garzón, M. B., 2003. Mixed duopoly. Merger and multiproduct firms. Journal of Economics 80 (1), 27-42.

[14] Matsumura, T., 2003. Endogenous role in mixed markets: a two-production-period model. Southern Economic Journal 70 (2), 403-413.

[15] Dadpay, A., Heywood, J. S., 2006. Mixed oligopoly in a single international market. Australian Economic Papers 45 (4), 269-280. 
[16] Ohnishi, K., 2010. Domestic and international mixed models with price competition. International Review of Economics 57 (1), 1-7.

[17] Bös, D., 1986. Public Enterprise Economics. North-Holland, Amsterdam.

[18] Bös, D., 2001. Privatization: A Theoretical Treatment. Clarendon Press, Oxford.

[19] Vickers, J., Yarrow, G., 1988. Privatization: An Economic Analysis. MIT Press, Cambridge MA.

[20] Cremer, H., Marchand, M., Thisse, J.-F., 1989. The public firm as an instrument for regulating an oligopolistic market. Oxford Economic Papers 41 (1), 283-301.

[21] Nett, L., 1993. Mixed oligopoly with homogeneous goods. Annals of Public and Cooperative Economics 64 (3), 367-393.

[22] Gronberg, T. J., Hwang, H., 1992. On the privatization of excludable public goods. Southern Economic Journal 58 (4), 904-921.

[23] Fjell, K., Pal, D., 1996. A mixed oligopoly in the presence of foreign private firms. Canadian Journal of Economics 29 (3), 737-743.

[24] George, K., La Manna, M., 1996. Mixed duopoly, inefficiency, and public ownership. Review of Industrial Organization $11(6), 853-860$.

[25] White, M. D., 1996. Mixed oligopoly, privatization and subsidization. Economics Letters 53 (2), 189-195.

[26] Poyago-Theotoky, J., 2001. Mixed oligopoly, subsidization and the order of firms' moves: an irrelevance result. Economics Bulletin 12 (3), 1-5.

[27] Myles, G., 2002. Mixed oligopoly, subsidization and the order of firms' moves: an irrelevance result for the general case. Economics Bulletin 12 (1), 1-6.

[28] Tomaru, Y., 2006. Mixed oligopoly, partial privatization and subsidization. Economics Bulletin 12 (5), 1-6.

[29] Kato, K., Tomaru, Y., 2007. Mixed oligopoly, privatization, subsidization and the order of firms' moves: several types of objectives. Economics Letters 96 (2), 287-292.

[30] Anderson, S. P., de Palma, A., Thisse, J.-F., 1997. Privatization and efficiency in a differentiated industry. European Economic Review 41 (9), 1635-1654.
[31] Matsumura, T., 1998. Partial privatization in mixed duopoly. Journal of Public Economics 70 (3), 473-483.

[32] Mujumdar, S., Pal, D., 1998. Effects of indirect taxation in a mixed oligopoly. Economics Letters 58 (2), 199-204.

[33] Pal, D., White, M. D., 1998. Mixed oligopoly, privatization, and strategic trade policy. Southern Economic Journal 65 (2), 264-281.

[34] Sasaki, D., Wen, M., 2003. On optimal privatization. In: Baldassarri, M. and Lambertini, L. (Eds.), Antitrust, Regulation and Competition. Palgrave Macmillan, New York, pp. 193-216.

[35] Bárcena-Ruiz, J. C., Garzón, M. B., 2005. Economic integration and privatisation under diseconomies of scale. European Journal of Political Economy 21 (1), 247-267.

[36] Bosi, S., Girmens, G., Guillard, M., 2005, Optimal privatization design and financial markets. Journal of Public Economic Theory 7 (5), 799-826.

[37] Chang, W. W., 2005. Optimal trade and privatization policies in an international duopoly with cost asymmetry. Journal of International Trade and Economic Development 14 (1), $19-42$.

[38] Chao, C. C., Yu, E. S. H., 2006. Partial privatization, foreign competition, and optimal tariff. Review of International Economics 14 (1), 87-92.

[39] Han, L., Ogawa, H., 2008. Economic integration and strategic privatization in an international mixed oligopoly. FinanzArchiv 64 (3), 352-363.

[40] Roy chowdhury, P., 2009. Mixed oligopoly with distortions: first best with budget-balance and the irrelevance principle. Economics Bulletin 29 (3), 1885-1900.

[41] Wang, L. F. S., Wang, Y., Zhao, L., 2009. Privatization and efficiency gain in an international mixed oligopoly with asymmetric costs. Japanese Economic Review 60 (4), 539-559.

[42] Bárcena-Ruiz, J. C., 2007. Endogenous timing in a mixed duopoly: price competition. Journal of Economics 91 (3), 263-272.

[43] Barcena-Ruiz, J. C., Garzón, M. B., 2007. Capacity choice in a mixed duopoly under price competition. Economics Bulletin $12(26), 1-7$. 